\title{
URBAN MAGNETISM IN THE GLOBAL CITY FRAMEWORK: EXPLORING THE LINK BETWEEN URBAN FUNCTIONS AND POPULATION GROWTH
}

\author{
Jelena J. Stankovićc ${ }^{\text {, Ivana Marjanović }}{ }^{2}$, Saša Drezgićc
}

\begin{abstract}
University of Niš, Faculty of Economics, Serbia, ORCID: 0000-0002-9875-9861, jelena.stankovic@eknfak.ni.ac.rs; University of Niš, Faculty of Economics, Serbia, ORCID: 0000-0002-9526-0467, ivana.veselinovic@eknfak.ni.ac.rs; University of Rijeka, Faculty of Economics, Croatia, ORCID: 0000-0002-7712-8112, sasa.drezgic@efri.hr.
\end{abstract}

\begin{abstract}
Dynamics in global processes have led to a number of political, economic and cultural changes that have resulted in the emergence of global cities. In the hierarchy of global cities, those who successfully use the limited available resources and offer an adaptable and flexible living environment, represent the most competitive global cities. Nonetheless, accelerated globalization has conditioned direct competition of global cities for different resources, and one of the most desirable being highly-skilled, talented and creative residents. In such conditions, city leaders face the need to understand the concept and factors of urban magnetism. The analysis of the determinants of urban magnetism can facilitate the formulation of concrete actions aimed at increasing the attractiveness of the city, which ultimately leads to the preservation of long-term socio-economic development of cities. Although financial wellbeing and incentives were considered to be a key factor of urban magnetism, contemporary research approaches have emphasized other factors that may influence urban attractiveness. Starting from that point of view, this paper aims to identify the main urban functions that influence the cities' size with an analysis focusing on global cities worldwide. The panel regression analysis is applied to the sample of 39 global cities over the period from 2013 until 2019 and the data on urban functions are obtained from the Global Power City Index (GPCl). The results indicate that the size of the global cities population is positively affected by urban functions related to the cultural interaction and accessibility, while research and development function influences negatively on the size of the urban population. Results of the paper led to the conclusion that contemporary urban management strategies need to be defined and implemented aimed at improving the urban magnetism beyond economic performance of the city, focusing on sustainability and urban quality of life.
\end{abstract}

Keywords: Cities, population, panel data, regression analysis.

JEL Classification: C33, J11, R12.

APA Style Citation: Stanković, J. J., Marjanović, I., \& Drezgić, S. (2021). Urban Magnetism in the Global City Framework: Exploring the Link between Urban Functions and Population Growth. E\&M Economics and Management, 24(4), 4-21. https://doi.org/10.15240/tul/001/2021-4-001

\section{Introduction}

The competitiveness of cities is most often associated with their economic performances, but there is a growing consensus that other factors must be observed as relevant (Huggins et al., 2014). The performance of modern cities, in addition to hard infrastructure, is increasingly influenced by the availability and quality of social infrastructure (Caragliu et al., 2011). The development potential and competitiveness of the city depend on the quality of social infrastructure, i.e., human and social capital. 
Human capital is emerging as a major driver of innovation and economic growth. Therefore, attracting highly skilled workers plays a fundamental role in the perspective of cities since the economic progress of cities depends on the knowledge of highly skilled workers (Buch et al., 2017). The impact of population growth on urban areas is multidimensional, in addition to the impact on infrastructure, economy and patterns of social interaction, population growth also affects the environment (Marshall, 2007).

The constant growth of the urban population led to the fact that in 2007 the share of rural and urban population was almost equal (Ritchie \& Roser, 2018), while today the share of the urban population exceeded the share of the rural population. The growth of the urban population led to the fact that currently $82 \%$ of North America's population is already urbanized, while $81 \%$ of Latin America's and the Caribbean's, $74 \%$ of European's, $68 \%$ of Oceania's, and $50 \%$ of Asian's inhabitants live in cities (United Nations, 2019). As the urban population increases, the environment becomes more congested. In an industrial society, every human being has a negative influence on the environment through the destabilization of ecological systems by the use of renewable and non-renewable resources (Ehrlich \& Holdren, 1971). Urban settlements have the greatest impact on the environment. Although cities occupy only $3 \%$ of the world's landmass, they account for up to $80 \%$ of energy consumption and $75 \%$ of the world's greenhouse gas emissions (United Nations, 2020). On the other hand, cities generate more than $80 \%$ of global GDP (World Bank, 2020), and they represent educational, financial, and cultural centres that attract artists, tourists and new residents.

Consequently, the challenge facing cities is manifold - how to accommodate a constantly growing urban population and provide it with a satisfactory quality of life, with a functional communal infrastructure and services that meet their needs, while reducing the negative impact on the environment.

Studying urban growth and understanding the basic factors of growth is important for predicting its broad impacts (Marshall, 2007). Therefore, the question arises as to what affects the size of cities, or in other words, what are the determinants of urban magnetism of global cities. In order to answer the stated research question, the multiple regression analysis on panel data was applied on the sample of 39 global cities from the Mori Memorial database, during the seven-year period, ending in 2019.

The research contributes to the existing literature in two ways. From a theoretical point of view, the paper contributes to the existing literature related to urban growth and the attractiveness of cities embodied through the concept of urban magnetism. From a practical point of view, the paper offers an empirical study of the determinants of urban magnetism represented by the urban functions of cities and provides insight into the importance of each of the functions for the development of global cities. The novelty of the research is reflected in the possibility of applying econometric methodology in the analysis of panel data of cities in order to provide assistance in researching the determinants of urban magnetism and consequently creating urban development strategies.

The rest of the paper is structured as follows: an overview of the literature related to global cities and determinants that affect the size of global cities is provided in the second section, the third section offers the research methodology applied in the paper, the fourth section provides empirical data and analysis, while the fifth section presents results and discussions. Concluding remarks are presented in the sixth section.

\section{Theoretical Background}

Starting from the 1970s, the field of urban studies developed rapidly. The initial research focus was on examining urban life and urban settlements based on the circulation of capital and the flow of power and knowledge (McCann, 2004), while in the 1980s the focus shifts on the concept of the world city (Friedmann, 1986), as a term that defines the emerging urban hierarchy in the age of globalization (Machimura, 2019). The basic characteristic of the world's cities is that they represent the starting point for global capital from which command and control over capitalist accumulation are implemented (Bassens \& Van Meeteren, 2015). Within the world cities concept, urban areas are seen as important organizational nodes of the world economy as stipulated by Taylor (1997). The concept of world cities was further developed by Taylor who has established the Globalization and World Cities Research Network (GaWC) in 
1998 which aims to explore relations between world cities in the context of globalization (GaWC, 2021). The network of world cities is represented as a network with three levels of structure where cities are identified as nodes, the world economy as the level of the supranodal network and advanced producer service firms that represent the critical subnodal level (Taylor, 2001).

Further development in the field of urban studies has led to a distinction between the world and global cities where world cities are seen as centres of power and control while global cities are seen as production centres for the inputs that create the ability for global control (Derudder et al., 2011). Heenan (1977) was the first to use the term global city (Parnreiter, 2013). Cohen (1981) viewed the functions of global cities in a broader sense in terms of cities becoming global not only because of the location of corporate headquarters but also because they are main centres of corporate-related services and part of a global network of financial centres. The global city is a centre that, in addition to being a strong political, educational, cultural and trade centre, is also the seat of international companies and international organizations, as well as a financial, service, innovation and technology centre. Global cities represent centres for financing and servicing investment, international trade and the headquarters operations, as well as strategic places for the production of today's leading economic sectors (Sassen, 2004). Jacobs (2019) defined a global city as large urban agglomerations of people, firms, capital, and infrastructure that served as vital centres of corporate governance, government, and culture. Global cities are especially relevant as reputable economic, political, cultural, and social centres. The global city is characterized by great globalization and high regional integration, representing a network centre that has close ties with cities in the country and abroad (Wang et al., 2020). Globalization as a process of integration of the world economy (Radulović \& Kostić, 2020) was one of the preconditions for the emergence of global cities. According to Goerzen et al. (2013), three key features distinguish global cities: a multicultural environment; high degree of connection with local and global markets; and a significant level of advanced producer services. Global cities are at the top of the hierarchy of the global economy, where the position of the city in the hierarchy depends on the nature and degree of integration into the global economy and the impact that the city has by representing financial and production services, cultural or technological centre (Forrest et al., 2004). Besides, the success of global cities in attracting new residents, primarily skilled labour, is one of the factors determining the strength of global cities. Based on the increase in the number of inhabitants, the degree of economic development and the relative attractiveness of a certain place can be assessed (Partridge \& Rickman, 2003). The urban magnetism or attractiveness of cities represents the ability of the city to meet the preconditions based on which those who already live there do not want not to move to another place or based on which potential residents would like to move there (Fertner et al., 2015). The European Commission (2006) underlines several important features of cities attractiveness: an effective economic structure, access to public services and institutions, good accessibility and mobility, stimulating technological, cultural, and touristic environments as well as attractive natural and physical environment. The existence of city magnetism imposes the need to study the reasons for the emergence of magnetism and the basic determinants of the attractiveness of cities. On the one hand, urban life has obvious economic and social costs reflected in congestion costs, commuting time, but also crime and pollution rates that have been found to deteriorate with increasing city size (Glaeser, 1998; Duranton, 1999). On the other hand, there are certain benefits of living in cities, which are primarily reflected in social and economic benefits. From the social aspect, cities provide a greater opportunity for socialization, access to greater cultural content, access to better educational opportunities. From an economic point of view, cites offer access to a better and more diverse supply of jobs, greater availability of raw materials and labor for the needs of industrial development (Duranton, 1999), as well as a greater opportunity to create knowledge and innovation (Verginer \& Riccaboni, 2021). In the era of globalization, cities act as key channels for the flow of knowledge that is considered necessary to achieve competitiveness. Cities, and especially global cities, achieve high concentrations of human capital and skills and as such act as 
magnets and attract both international and interregional flows of capital and labor (Dijkstra et al., 2013). Increasing the attractiveness of places is usually associated with better economic performance of cities and better job opportunities, which attracts new residents and increases the size of cities (Glaeser, 2011). In addition, along with economic factors, factors such as housing affordability and a favorable living environment also have a positive impact on population inflows (Barreira et al., 2019). with cities with higher livability expecting higher population growth. Thus, cities with a more developed livability function attract a larger number of residents. In addition, a clean environment, a vibrant business climate, and a solid social and cultural infrastructure have been identified in the literature as some of the factors of magnetism (Thite, 2011). Therefore, a favorable impact of urban functions related to the environment and cultural interaction can be expected.

Therefore, despite the widespread belief that financial incentives are a key factor in the decision to relocate, other benefits that cities offer can be equally attractive for potential residents such as a healthy environment, the innovative potential of the city, the availability of green spaces, the availability of cultural facilities and contents or the level of safety of inhabitants. With this in mind, cities must strive to promote the benefits to potential inhabitants and identify shortcomings that require further improvement, as international competition for magnetism is vital in determining the future development success of a city (Ichikawa et al., 2017).

However, the most of urban economics studies are primarily focused on the distribution of the cities' size (Su, 2020; Song \& Zhang, 2002; Overman \& loannides, 2001; Hsu, 2012; Xu \& Zhu, 2009; loannides \& Skouras, 2013; Gabaix \& loannides, 2004; Fang et al., 2017), rather than the determination of main factors that influence the size of the urban population. There is a rivalry among global cities to attract companies, tourists, investors, new citizens, and most of all skilled workforce (Zenker et al., 2013). To maintain their competitiveness, cities are required to unceasingly invest in human capital and to entice a qualified workforce. In addition, attracting a skilled workforce has a positive effect on the city's overall attractiveness to other actors, such as companies and investors (Zenker, 2009).
There is a positive association concerning population growth in a given location and externalities they produce (De Noni et al., 2014).

Several studies have addressed city attractiveness features in an attempt to determine factors of urban population size and growth. De Noni et al. (2014) examined the attractiveness of the city of Milan and revealed that the most influential features of Milan's attractiveness are education and culture, while healthcare, tourism, social services, and internationalization level although significant are less important. Furthermore, the quality of the environment and pollution harm the city's ability to attract talented people. Da Mata et al. (2007) investigated the features of city sizes and their growth on a sample of 123 Brazilian agglomerations and revealed that labour force quality, improvement of market of goods, reductions in rural income opportunities, and decrease in intercitytransport costs have strong influences on city growth while local crime and violence impose the growth. Haque and Patel (2018) examined the determinants of metro city growth in India and revealed that the geographical position and the quality of public services represent the main determinants of the cities' growth. Sridhar (2010) investigated determinants of urban population and economic growth in India and discovered that the main determinants of cities' growth were manufacturing, proximity to large cities, and public services. Barreira et al. (2017) analysed the dynamics of the population in the cities in Portugal over the period from 1991 to 2011 and revealed that favourable climate conditions, employment rates, and a higher proportion of middle-aged vacant houses increase urban attractiveness. Duranton and Puga (2014) identified four basic drivers of the population growth of cities in developed economies: transportation and housing supply, amenities, agglomeration effects, and technology and shocks to specific cities or industries. Duranton (2016) examined the drivers of population growth in Colombian cities between 1993 and 2010 and discovered that fertility rate, wage level, education and urban amenities represent the significant determinants of population growth. Deliktas et al. (2013) examined the determinants of urban growth in Turkey and revealed that migration, location of the city, fertility rate, 
agglomeration in services and specialization in the manufacturing industry have a positive influence, while schooling rate has a negative influence on the urban population growth. Romão et al. (2018) have examined the factors of urban attractiveness in 40 global cities from Mori Memorial database using latent growth curve model and discovered that economy and cultural interaction have a positive influence on the population growth, while livability, environment and research \& development have a negative influence on the population growth. Alvarez-Dias et al. (2018) offered an extensive literature review regarding factors of urban growth and conducted an empirical analysis of the determinants of population growth in EU sub-regions over the period 2000-2010.

In this context, as stated above, this paper aims to analyse urban magnetism within the global cities framework and to contribute to a better understanding of population dynamics in modern cities. The basic assumption is that there is a direct impact of the urban functions of global cities on the size of cities measured by the size of population.

\section{Research Methodology}

To evaluate the determinants of city's magnetism, multiple regression analysis on panel data was applied. Panel data represent a combination of time series data and crosssectional data as they provide a temporal and cross-sectional dimension at the same time (Biørn, 2016). These data represent a special form of pooled data in which the same crosssectional unit is observed over time. Stated characteristics of the panel data allow all relevant information from the sample to be used in estimating regression parameters. The general form of the panel data regression model can be represented as (Baltagi, 2008):

$$
\begin{aligned}
& y_{i t}=\alpha+X_{i t}^{\prime} \beta+u_{i t}, \quad i=1,2, \ldots, N, \\
& t=1,2, \ldots, T,
\end{aligned}
$$

where:

$y_{i t}=$ the value of the dependent variable for the $i^{\text {th }}$ observation unit in the period $t$;

$\alpha=$ intercept;

$X_{i t}=i^{\text {th }}$ observation on $\mathrm{K}$ explanatory variables

in the period $t / \mathrm{K}$-dimensional vector on explanatory variables;

$\beta=\mathrm{K} \times 1$ vector of regression parameters; $u_{i t}=$ disturbance term, wherein $u_{i t}=\mu_{i}+v_{i t}$; $\mu_{i}$ represents the unobservable individualspecific effect; and $v_{i t}$ represents the remainder disturbance.

In the model with fixed effect $\mu_{i}$ are presumed to be fixed parameters to be estimated, while in the model with random effects $\mu_{i}$ can be presumed random. The panel data regression model includes a cross-sectional and temporal dimension which raises the question of modeling the cross-sectional and temporal dependence of selected variables in the model. The choice of an adequate model specification first implies testing of the variability of regression parameters (heterogeneity), which will determine the existence and test the significance of individual and/or temporal effects. For this purpose, tests based on variance decomposition (F-test) or Lagrange multiplier tests (Breusch-Pagan test) can be used. The null hypothesis of F-test states that all fixed effects are jointly equal to zero, and the rejection of the null hypothesis leads to the selection of the model with fixed effects. The null hypothesis of the Breusch-Pagan Lagrange multiplier test is that all individualspecific variance components are zero, and the rejection of the null hypothesis implies that the model with random effects is appropriate.

To select between the model with fixed effects and the model with random effects, the Hausman test can be applied. The null hypothesis of the Hausman test assumes that both estimators are consistent and should display similar results (Cameron \& Trivedi, 2009). If the null hypothesis is not rejected, the random effect estimator is concluded to be consistent and more efficient. On the other hand, if the null hypothesis is rejected, it is concluded that the estimator of the random effect is not consistent and the use of a fixed effect estimator is proposed.

After the selection of appropriate model specification, it is necessary to take into account several assumptions of panel data models, due to the existence of frequent violations of standard assumptions, regarding the panel data structures. Therefore, the assumptions concerning multicollinearity, homoscedasticity, autocorrelation and cross-sectional correlation should be tested.

If the existence of a large correlation between two or more explanatory variables is identified in the model, the problem of 
multicollinearity is considered to be present. The Variance Inflation Factor test (VIF) can be used to identify the presence of multicollinearity between independent variables. The VIF value greater than 10 indicates the existence of strong multicollinearity. The standard panel data models assume that the disturbances are homoskedastic with the same variance across time and individuals (Baltagi, 2008). The presence of heteroscedasticity can be detected by applying several tests, whereby the modified Wald test for the groupwise heteroscedasticity will be applied in this paper. Under the null hypothesis, the variance of the error is the same for all individuals, and the rejection of the null hypothesis indicates the presence of heteroscedasticity. The occurrence of autocorrelation arises in situations when random errors between the observation periods are correlated, which leads to the underestimation of the standard errors of the coefficients (Chiulli, 2018). Several tests can be applied to test autocorrelation, whereby the Wooldridge test will be applied in this paper. Under the null hypothesis, there is no first-order autocorrelation, and the rejection of the null hypothesis signifies that the autocorrelation is present. Cross-sectional correlation occurs in the situations where the residuals are correlated across entities which can lead to the results being biased (Hoechle, 2007). To test for crosssectional dependence the Pesaran's test will be used, where the null assumes that there is no correlation among residuals. The rejection of the null indicates the existence of cross-sectional dependence.

\section{Empirical Data and Analysis}

To determine the link between urban functions and the urban population, data obtained from the Global Power City Index (GPCl) database published by the Mori Memorial Foundation Institute for Urban Strategies were used. The $\mathrm{GPCl}$ index assesses the strengths and weaknesses of cities in various areas such as attracting investment, creating wealth, strengthening social development, accessing social capital and networks, fostering integrated sustainability and using technological and human resources in competitiveness and productivity globally and locally (Kourtit et al., 2013). The index evaluates urban performance across six urban functions: Economy, Research and Development, Cultural Interaction, Livability, Environment, and Accessibility. Each of these urban functions evaluates some aspect of urban life. Economic performance and economic condition of cities are assessed through the Economy function. Suitability of the environment for innovation, the educational and scientific capacity of cities is evaluated by the Research and Development function. Influential potential, cultural capacity, and tourist amenities of the cities are assessed through Cultural Interaction function. The suitability of cities for life and quality of life is measured by the Livability function. Environment function evaluates the condition of the natural environment, while the Accessibility function incorporates the suitability of inner-city and international transport (Wang, 2019). More details on urban functions and indicators within each of the function can be found in Global Power City Index reports (GPCl, 2019).

Despite a large number of global cities, some of them share similar characteristics and can be grouped into clusters based on their performance of urban functions. Using cluster analysis, five different clusters of global cities can be identified.

\section{Tab. 1: Structure of clusters}

\begin{tabular}{c|l} 
Cluster & \multicolumn{1}{c}{ Cities } \\
\hline I & $\begin{array}{l}\text { Barcelona, Madrid, Berlin, Brussels, Milan, Vienna, Kuala Lumpur, Osaka, Amsterdam, } \\
\text { Frankfurt, Toronto, Vancouver, Copenhagen, Stockholm, Zurich, Geneva, Sydney }\end{array}$ \\
\hline II & Cairo, Mumbai, Istanbul, Moscow, Bangkok, Mexico City, Sao Paulo \\
\hline III & Boston, Los Angeles, San Francisco, Chicago, Washington DC, Taipei \\
\hline IV & Seoul, Singapore, Hong Kong, Beijing, Shanghai \\
\hline V & Paris, Tokyo, London, New York \\
\hline
\end{tabular}


The first cluster represents livable, ecofriendly cities and consists of mostly world metropolises. The second cluster consists of economically and technologically poor but livable cities. The third cluster represents innovative, accessible cities and mainly encompasses cities from the United States. The fourth cluster consists mainly of cities in Southeast and East Asia and is characterized by above-average economic performance, while the fifth cluster consists of the most powerful global cities that achieve superior performance in all urban functions. Over time, changes in clusters were trivial, and are reflected primarily in changes in the structure of the fourth and fifth clusters, where the cities of Hong Kong, Singapore and Seoul in the period from 2016 to 2018 belonged to the group of most powerful global cities. Fig. 2 provides an overview of the evolution of urban functions over time by clusters.

In addition to the division of global cities into clusters, in order to analyze the effects of capitals, global cities were divided into two groups, those representing capitals, and other non-capital global cities and the values of urban functions are compared. To determine whether there is a statistically significant difference in the realized values of urban functions between these two groups of cities, a t-test was conducted (Tab. 2).

The results indicate that there is statistically significant difference in performance of capital global cities and other non-capital global cities when it comes to Cultural interaction and Accessibility urban functions. In particular, the average values of the Cultural interaction and Accessibility functions are higher in the capital cities for 35.011 and 19.039, respectively, compared to the average values of these function in other non-capital global cities. However, when it comes to other urban functions, there is no significant difference between these two groups of global cities.

In order to evaluate the determinants that affect the magnetism of cities, regression analysis was performed on panel data, using the number of inhabitants in cities as a dependent variable. The number of inhabitants in cities refers to the population size of metropolitan area. Fig. 3 provides an overview of number of inhabitants in the cities in the last analysed year and the population growth for the analysed period of time.

\section{Fig. 1: Division of cities into clusters}

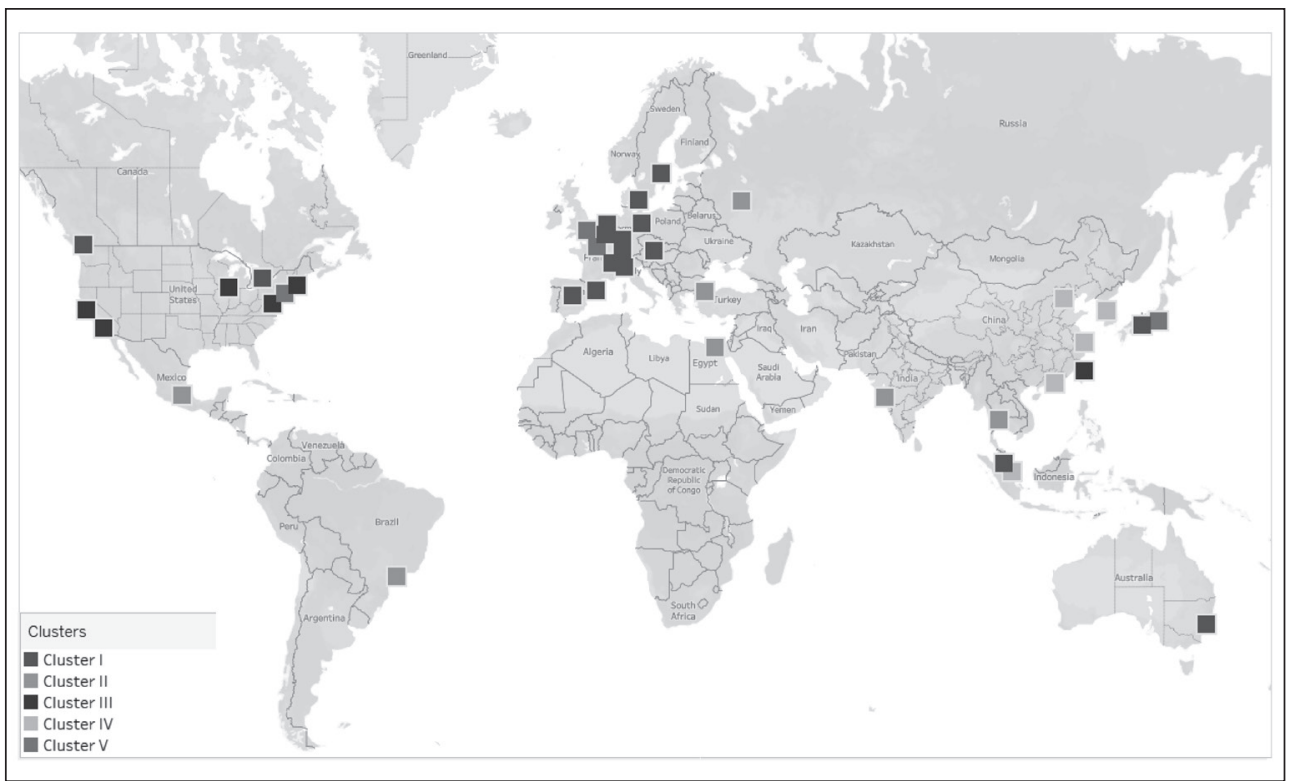

Source: own 


\section{Tab. 2: \\ Testing of differences between urban functions of capital and non-capital global cities}

\begin{tabular}{l|c|c}
\multirow{2}{*}{\multicolumn{1}{c|}{ Urban functions }} & \multicolumn{2}{c}{ T-test for equality of means } \\
\cline { 2 - 3 } & Sig. (2-tailed) & Mean difference \\
\hline Economy & 0.971 & 0.16881 \\
\hline Cultural interaction & 0.000 & 35.01109 \\
\hline Research and development & 0.122 & -9.09945 \\
\hline Livability & 0.606 & -12.56626 \\
\hline Environment & 0.142 & -5.69608 \\
\hline Accessibility & 0.002 & 19.03907 \\
\hline
\end{tabular}

\section{Fig. 2: Evolution of urban function over time by clusters}

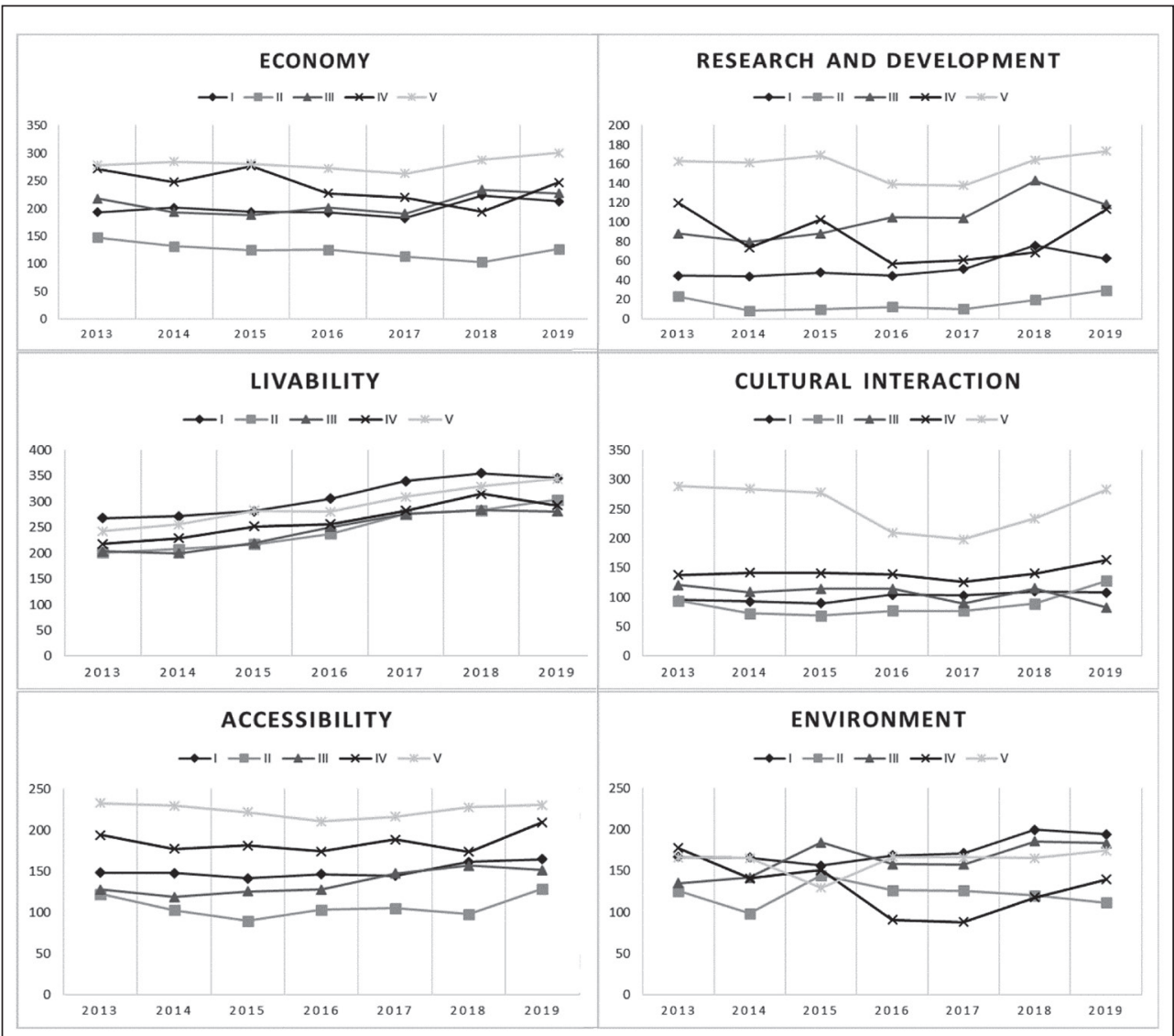

Source: own based on the data from GPCl $(2013,2014,2015,2016,2017,2018,2019)$ 


\section{Fig. 3: The size of the population of global cities in 2019 and the relative population change for the period from 2013 to 2019}

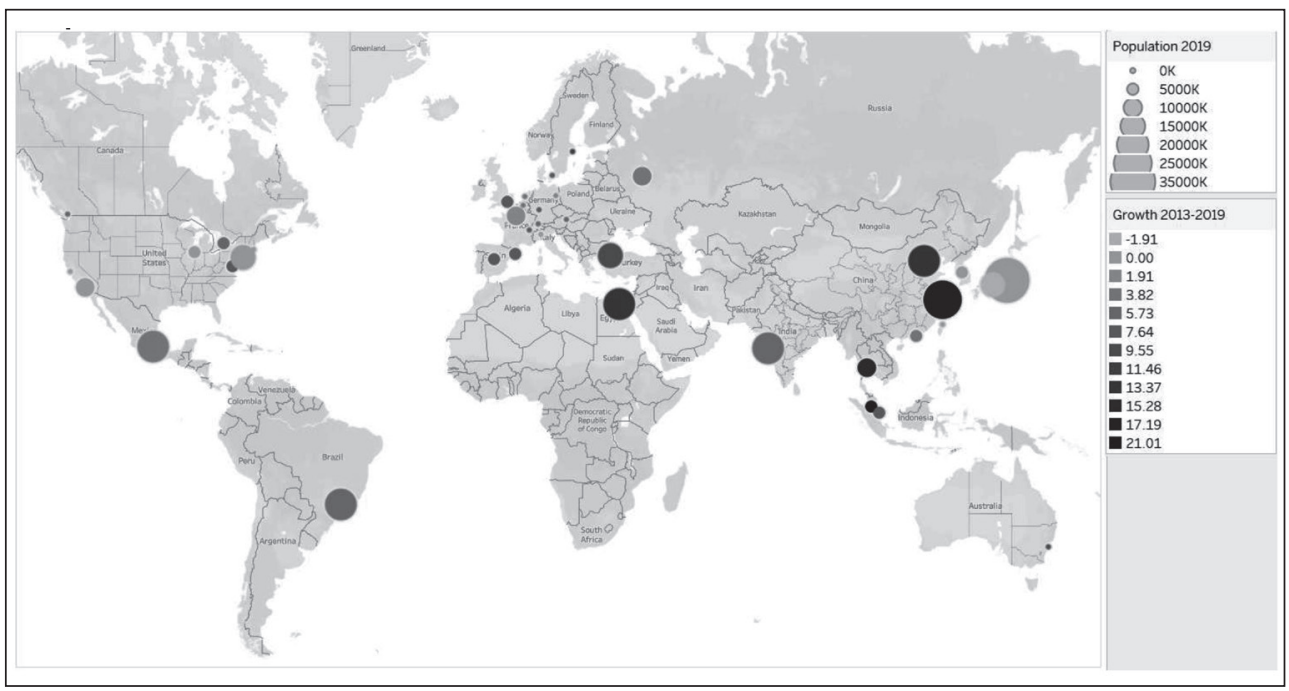

Source: own

Regarding the presented changes in the population size in the observed period, Kuala Lumpur has recorded the biggest growth, followed by Shanghai, Bangkok, Cairo and Beijing. Stockholm and Sydney also achieved population growth of more than $10 \%$ in the observed period. Kuala Lumpur is the most industrialized and economically fastest growing city in Malaysia. Although Kuala Lumpur is also a city facing a declining birth rate, the working age population is increasing due to the growing influx of population. The rapid development of the city has led to an influx of mostly lowskilled foreign workers, mostly from Southeast Asian countries. According to the survey by InterNations on expats living in various cities Malasya is ranked as the fourth best place for expatriates in the world (InterNations, 2021). When it comes to Bangkok, Beijing, Shanghai, Stockholm and Sydney, the increase in population is primarily due to the settlement of inhabitants mainly from rural areas, since these cities are important economic centres. Among the cities that recorded a population increase of more than $10 \%$, only Cairo achieved an increase due to natural population trends, as it has a very high natural growth in spite of inadequate amenities.
On the other hand, Osaka is the only city that has recorded a decline in population in the analyzed period. However, if the change in the number of inhabitants in 2019 compared to 2018 is analyzed, it can be noticed that the depopulation trend affects a larger number of cities. In addition to Osaka, all the cities in the observed sample that are in the United States, except Washington, have recorded a decline in population. Moreover, the decline in population in 2019 compared to 2018 is recorded in Tokyo and Seoul. According to Hartt (2018), urban shrinkage of global cities is mainly due to the impact of economic changes combined with demographic changes characterized by declining fertility rates and rapid population aging.

For the purpose of the analysis the logtransformation of data was performed and the following model is estimated:

$$
\text { Population }_{i t}=\beta_{0}+\beta_{1} \text { Economy }_{i t}+
$$
$+\beta_{2} R D_{i t}+\beta_{3}$ CulInteraction $_{i t}+$ $+\beta_{4}$ Livability $_{i t}+\beta_{5}$ Environment $_{i t}+$ $+\beta_{6}$ Accessibility $_{i t}+\varepsilon_{i t}$,

where:

$\beta_{0}, \beta_{1}, \ldots, \beta_{6}=$ intercept and slope coefficients; $\varepsilon_{i t}=$ disturbance term; $i=1, \ldots, 39 ; t=1, \ldots, 7$. 


\begin{tabular}{l|c|c} 
& Chi-squared statistic & Probability \\
\hline HO: Difference in coefficients not systematic & 48.50 & 0.0000 \\
\hline
\end{tabular}

Before performing regression analysis, it is necessary to select the appropriate model specification. The results of Breusch-Pagan Lagrange multiplier test and the joint F-test reject pooled OLS assumption, while the results of the Hausman test are in favour of the model with fixed effects (Tab. 3).

The results of the estimated fixed effects model are presented in Tab. 4. The regression is statistically significant (value of F-statistic is 51.63 at the significance level of $1 \%$ ). All analysed explanatory variables (except Economy) have a statistically significant impact on the dependent variable at a significance level of $1 \%$.
To verify obtained results the model should be tested for the existence of heteroscedasticity, cross-sectional dependence, multicollinearity and autocorrelation.

The presence of heteroscedasticity is tested using modified Wald test for the groupwise heteroscedasticity in the fixed effect regression model and the obtained statistics show that the model suffers from heteroscedasticity (Tab. 5).

The cross-sectional independence is tested using the Pesaran's test of cross-sectional independence and the results reveal the existence of cross-sectional dependence (Tab. 6).

\section{Tab. 4: Fixed effects model results}

\begin{tabular}{l|c|c|r|r|r|c}
\multicolumn{1}{c|}{ Population } & Coefficient & Std. err. & \multicolumn{1}{c|}{$\mathbf{T}$} & $\mathbf{P}>|\mathbf{t}|$ & \multicolumn{2}{|c}{ [95\% conf. interval] } \\
\hline Economy & -0.0088238 & 0.0183729 & -0.48 & 0.632 & -0.0450261 & 0.0273785 \\
\hline RD & -0.0304703 & 0.007297 & 4.18 & 0.000 & 0.0160921 & 0.0448485 \\
\hline Cullnteraction & 0.0184149 & 0.0109276 & 1.69 & 0.093 & -0.0031172 & 0.039947 \\
\hline Liveability & 0.0499532 & 0.0081602 & 6.12 & 0.000 & 0.0338741 & 0.0660323 \\
\hline Environment & -0.0219429 & 0.0086289 & -2.54 & 0.012 & -0.0389456 & -0.0049403 \\
\hline Accessibility & 0.0615731 & 0.018211 & 3.38 & 0.001 & 0.0256896 & 0.0974565 \\
\hline cons & 14.95816 & 0.1212552 & 123.36 & 0.000 & 14.71923 & 15.19708 \\
\hline
\end{tabular}

Source: own

Tab. 5: Results of the modified Wald test

\begin{tabular}{c|c} 
Chi-squared & Probability \\
\hline $3,981.40$ & 0.0000 \\
\hline
\end{tabular}

\section{Tab. 6: Pesaran's test of cross-sectional independence}

\begin{tabular}{c|c} 
Value & Probability \\
\hline 4.548 & 0.0000 \\
\hline
\end{tabular}




\section{Tab. 7: Variance inflation factor values}

\begin{tabular}{l|c}
\multicolumn{1}{c|}{ Variable } & VIF \\
\hline RD & 2.95 \\
\hline Economy & 2.68 \\
\hline Cultural interaction & 2.01 \\
\hline Accessibility & 1.80 \\
\hline Environment & 1.27 \\
\hline Livability & 1.15 \\
\hline
\end{tabular}

\section{Tab. 8: Wooldridge test for autocorrelation in panel data}

\begin{tabular}{c|c} 
Value & Probability \\
\hline 562.472 & 0.000 \\
\hline
\end{tabular}

To examine the existence of multicollinearity of explanatory variables the variance inflation factor is used and the results indicate that there is no multicollinearity of explanatory variables since all variance inflation factor values are less than 10 (Tab. 7).

The existence of serial correlation in the idiosyncratic error term is examined using the Wooldridge's test for autocorrelation in panel data and the results reveal that the null hypothesis of no first order autocorrelation is rejected.

\section{Research Results and Discussion}

To account for the existence of serial correlation, heteroscedasticity and cross-sectional dependence the Driscol-Kraay estimation procedure is performed (Tab. 9).

The results indicate that Accessibility, Cultural Interaction and Research \& Development represent statistically significant determinants of cities' magnetism (at 10\% significance level), wherein Accessibility and Cultural Interaction have a positive influence, and Research \& Development function has a negative influence.

\section{Tab. 9: Regression with Driscoll-Kraay standard errors}

\begin{tabular}{l|c|c|c|c|c|c}
\multicolumn{1}{c|}{ Population } & Coefficient & Std. err. & $\mathbf{T}$ & $\mathbf{P}>|\mathbf{t}|$ & \multicolumn{2}{c}{ [95\% conf. interval] } \\
\hline Economy & -0.0088238 & 0.0214914 & -0.41 & 0.696 & -0.0614113 & 0.0437638 \\
\hline RD & -0.0304703 & 0.0146347 & 2.08 & 0.082 & -0.0053395 & 0.0662801 \\
\hline Cullnteraction & 0.0184149 & 0.0058526 & 3.15 & 0.020 & 0.004094 & 0.0327357 \\
\hline Liveability & 0.0499532 & 0.0259225 & 1.93 & 0.102 & -0.013477 & 0.1133833 \\
\hline Environment & -0.0219429 & 0.0164491 & -1.33 & 0.231 & -0.062193 & 0.0183067 \\
\hline Accessibility & 0.0615731 & 0.0099542 & 6.19 & 0.001 & 0.037216 & 0.0859301 \\
\hline _cons & 14.95816 & 0.1634643 & 91.51 & 0.000 & 14.55817 & 15.35814 \\
\hline
\end{tabular}


Although it was expected that the Economy function represents a significant factor of urban magnetism of cities, the results indicate that there is no statistically significant influence of the economic performance of the city on its size. There are several potential explanations. One is related to the issue of wrecking urban hierarchies. More specifically, the problem of inhibition of the socio-economic growth of the city due to the accumulation of an increasing number of inhabitants in the cities, which can upset the balance of the urban system (Sun et al., 2021). On the one hand, a larger city offers residents a better quality of life, not only by increasing income and job opportunities, but also by offering a pleasant living environment, while on the other hand, urbanization simultaneously causes urban problems that reduce employability and quality of life, such as long commute (Dang et al., 2020). There is evidence that the productivity of city follows the inverted U-shape function of the total urban employment. In particular, productivity increases with the size of the city up to a certain threshold of the population, after which the negative effects of agglomeration prevail (Frick \& Rodríguez-Pose, 2018). Therefore, better economic performance is not necessarily a determinant of urban magnetism, as this effect disappears after a certain time. Another potential explanation is related to the specific sample that was the subject of the analysis, since the analysed time period is relatively short and it is possible that the effects of the development of industries that benefit from agglomeration are not accounted, since it takes several years for such effects to manifest. Furthermore, although there is evidence in literature that population growth negatively affects the environment (Ehrlich \& Holdren, 1971), the results of the analysis do not indicate that there is a significant impact of urban functions related to the environment on population movements in global cities. Also, there is no statistically significant impact of livability urban function on population movements in global cities.

The function of Cultural Interaction consists of subgroups of indicators concerning the service sector, influential potential (measured by the number of cultural events and conferences), cultural facilities, visitor content, and international interaction. The competitiveness of cities can be improved by large cultural events because they can improve the image and attractiveness of the city, foster economic development, and improve infrastructure (Absalyamov, 2015). Culture enables cities to differentiate themselves, both from the point of view of residents and external workforces, investments and tourists (Montalto et al., 2019). Cultural content has a significant role in defining the recognisability of cities and refining their competitiveness in the modern world (Guzmán et al., 2017). The impact of culture on urban attractiveness is undeniable, and the cultural content offered by cities is a significant resource in urban development (Herrero et al., 2006). The quality of life of urban residents improves if there is greater availability of cultural content as it leads to the creation of a pleasant living environment, and mitigates the negative effects of excessive urbanization (Bandarin \& van Oers, 2012). Greater availability of cultural content leads to greater urban magnetism of global cities which is confirmed by the results of the analysis.

Cities are a place of concentration of a large part of the population, companies and employment, however, the migration flow of people to cities has brought into question some aspects of the quality of life of the residents (Rodrigues \& Franco, 2019). While on the one hand urbanization improves the quality of life of residents through increasing employment opportunities, income, as well as providing a pleasant living environment, on the other hand, urbanization causes various accessibility problems that reduce the quality of life (Dang et al., 2020). Accessibility refers to the ability of people to reach geographically dispersed attractions, activities, and amenities of all kinds (Solá et al., 2018). Accessibility function of global cities encompasses subgroups of indicators related to the international network, air transport capacity, transport comfortability (commuting time, traffic congestion and taxi fare), and inner-city transportation. Accessibility is relevant at all levels, from local development to global trade and is a prerequisite for meeting almost every economic need. Access to people, services and jobs is a basic factor in the economic vitality of the city and quality of life. However, various cities are facing declining accessibility due to accelerated urbanization and motorization. On the other hand, more 
accessible cities have better opportunities to address environmental degradation and reduced economic competitiveness caused by increasing traffic congestion and urban sprawl (Venter et al., 2019). As a result, more accessible cities are also more attractive to residents. Therefore, greater accessibility entails greater urban magnetism.

Cities are often labelled as the cradles of an innovative and creative environment (Johnson, 2008). One of the differences between urban and rural environments is that urban environments are more specialized, more diverse, richer, and more knowledge-intensive. (Glaeser, 2011). Research and Development function of global cities encompasses subcategories that concern innovation, research environment and academic resources. Cities represent a place of concentration of creative workforce and institutions that are direct generators of innovations (Shearmur, 2012). Urban innovation is fuelled by the diversity of the urban population and is based on the recombination of different knowledge and competencies (Johnson, 2008). Although the results of the model indicate that there is an inverse relationship between the population size and the Research \& Development function, it should not be interpreted that progress in the Research \& Development function causes the reduction of urban attractiveness, on the contrary, the obtained results indicate that in the observed sample of global cities, smaller cities outperform larger cities. Progress in the function of Research and Development leads to the creation of a more favourable environment for urban dwellers by increasing the quality of life through sounder education and decent employment opportunities which will ultimately affect the costs of living and lead to the slowing of urban growth (Romão et al., 2018).

\section{Conclusions}

Urban competitiveness has been the subject of increasing considerations and investigations in recent decades, especially when creating regional development policies, as urban areas are developing into centres of economic activity in the knowledge-based economies (Buch et al., 2017). Previous research has been focused on describing urban growth patterns as an ability to be more competitive and attract businesses, visitors, capital, accelerate population inflow and above all acquire skilled workforce and provide knowledge based urban development (Van Oort et al., 2009). As one of the main factors of urban competitiveness is human capital, the issue of attracting skilled labour to the urban area has become of paramount importance. Skilled workers represent the bearers of knowledge and competencies and are seen as competitive assets. However, unlike traditional resources, human resources are mobile, and cities should, in addition to financial incentives, offer other benefits such as a suitable living environment, quality cultural content, or good infrastructure, in order to attract and retain a skilled workforce (Hansen \& Niedomysl, 2009). Formerly, financial incentives were considered to be the main factor in the decision to relocate, but nowadays other benefits are equally attractive (Ichikawa et al., 2017). When it comes to attractiveness features in an attempt to determine factors of urban population size, the most of the studies are nationally oriented, analysing the patterns that occur in the observed metropolises, within a particular group of cities, or a region. Our research intended to bridge the lack of global perspective and to put in focus the magnetism of global cities.

The conclusions based on analysis of panel data of 38 global cities, over the period 2013 to 2019, clearly indicate that modern urban magnetism far exceeds the population's perception of financial well-being and focuses on segments such as cultural interaction and accessibility. The findings suggest that urban policies, when it comes to population growth and strengthening the human capital of the city, should go towards strengthening social and cultural interaction as a strong lever of urban magnetism. Furthermore, urban accessibility issues have been determined as another powerful mechanism of urban attractiveness, surpassing only physical accessibility, but it also encompassing accessibility to health care, public and social services, open spaces and other centres with high-quality social and cultural facilities.

Finally, the analysis reveals, as well, that R\&D urban functions represents significant magnetism feature, but in the opposite context, causing the reduction of urban attractiveness, due to the perceived higher standard of living in cities with a developed R\&D function and significantly higher cost of living. On the other hand, livability, economy, and environment as assessed urban functions are not determined 
as significant features of urban magnetism based on performances of global cities in the Mori Memorial database.

The contribution of this paper is reflected in the expansion of existing knowledge about the determinants of urban growth, focusing on world-wide perspective and magnetism of global cities. Based on econometric model results, greater availability of cultural content and higher accessibility improve the urban attractiveness, while on the other hand progress in innovation and research and development can contribute to the increase of the cost of living in the city and reduce the attractiveness of the city. The research covers a seven-year period, ending in 2019 , which is a solid time horizon of current data, and these results can be considered a valid basis, from the city actors' point of view, in the process of creating development strategies designed to increase the cities' urban magnetism.

The conducted research faces certain shortcomings. Firstly, although the research period covered is sufficient to draw valid conclusions, covering a longer period would help to better understand the effects of all functions on urban magnetism. The reason for selecting a shorter time frame is that a smaller number of global cities were covered before 2013 , so it was not possible to cover a longer period without reducing the sample size. Secondly, although the results of the research give certain general guidelines, it should be borne in mind that each city is a unique whole with its own characteristics and structures, and when creating development policies, the specifics of a particular city must be taken into account. Thirdly, the analysis uses data on changes in the total population, without considering in particular the changes caused by natural population movements and changes caused by migratory movements. The deeper analysis of these phenomena can contribute to a better understanding of urban magnetism, and will be the subject of further research.

Although the obtained results enable a comprehensive assessment of the impact of different urban functions on the magnetism of global cities, in the process of formulating particular development strategies it is necessary to be considered the individual characteristics of each city. Nevertheless, the results of the research can be used as a general guideline during the formulation of urban policies.
Further research in this area may be directed towards the inclusion of demographic variables, such as fertility rates, as well as the subjective perceptions of residents related to the various aspects of quality of life. Additionally, it is possible to examine the determinants of the magnetism of cities from the tourists' standpoint.

Acknowledgment: The research in this paper was conducted within the framework of activities on bilateral cooperation project "Researching capacity for implementation of smart cities as basis for sustainable urban development" financed by Ministry of education, science and technological development of Republic of Serbia and Ministry of science and education of Republic of Croatia. Supported by the Ministry of Science, Education and Technological Development of the Republic of Serbia (no. 45103-68/2020-14/200100) and by the University of Rijeka under the project "Pametni gradovi u funkciji razvoja nacionalnog gospodarstva" (uniri-drustv-18-255-1424).

\section{References}

Absalyamov, T. (2015). The influence of cultural and sport mega-events on sustainable development of the city. Procedia - Social and Behavioral Sciences, 188, 197-201. https://doi. org/10.1016/j.sbspro.2015.03.372

Alvarez-Dias, M., d'Hombres, B., Ghisetti, C., Pontarollo, N., \& Dijkstra, L. (2018). The Determinants of Population Growth: Literature review and empirical analysis (JRC Working Papers in Economics and Finance, No. 2018/10). Luxembourg: Publications Office of the European Union. Retrieved from https://publications.jrc.ec.europa.eu/repository/ bitstream/JRC112628/jrc112628_the _ determinants_of_population_growth_1.pdf

Baltagi, B. H. (2008). Econometric Analysis of Panel Data. Chichester: John Wiley \& Sons.

Bandarin, F., \& Van Oers, R. (2012). The Historic Urban Landscape: Managing Heritage in an Urban Century. Chichester: Wiley-Blackwell.

Barreira, A. P., Ramalho, J. J. S., Panagopoulos, T., \& Guimarães, M. H. (2017). Factors Driving the Population Growth and Decline of Portuguese Cities. Growth and Change, 48(4), 853-868. https://doi. org/10.1111/grow.12205

Barreira, A. P., Nunes, L. C., Guimarães, M. H., \& Panagopoulos, T. (2019). Satisfied but thinking about leaving: The reasons behind residential 
satisfaction and residential attractiveness in shrinking Portuguese cities. International Journal of Urban Sciences, 23(1), 67-87. https://doi.org/1 0.1080/12265934.2018.1447390

Bassens, D., \& Van Meeteren, M. (2015). World cities under conditions of financialized globalization: Towards an augmented world city hypothesis. Progress in Human Geography, 39(6), 752-775. https://doi. org/10.4324/9781315684871-61

Biørn, E. (2016). Econometrics of Panel Data: Methods and Applications. Oxford: Oxford University Press.

Buch, T., Hamann, S., Niebuhr, A., \& Rossen, A. (2017). How to woo the smart ones? Evaluating the determinants that particularly attract highly qualified people to cities. Journal of Urban Affairs, 39(6), 764-782. https://doi.org /10.1080/07352166.2017.1282765

Cameron, A. C., \& Trivedi, P. K. (2009). Microeconometrics Using Stata. College Station, TX: Stata Press.

Caragliu, A., Del Bo, C., \& Nijkamp, P. (2011). Smart Cities in Europe. Journal of Urban Technology, 18(2), 65-82. https://doi.or g/10.1080/10630732.2011.601117

Chiulli, R. (2018). Quantitative Analysis: An Introduction. Amsterdam: Gordon \& Breach Science Publishers.

Cohen, R. B. (1981). The new international division of labor, multinational corporations, and urban hierarchy. In M. Dear, \& A. J. Scott (Eds.), Urbanization and Urban Planning in Capitalist Society (pp. 287-315). London: Routledge. https://doi.org/10.4324/9781351068000-12

da Mata, D., Deichmann, U., Henderson, J. V., Lall, S. V., \& Wang, H. G. (2007). Determinants of city growth in Brazil. Journal of Urban Economics, 62(2), 252-272. https://doi. org/10.1016/j.jue.2006.08.010

Dang, Y., Chen, L., Zhang, W., Zheng, D., \& Zhan, D. (2020). How does growing city size affect residents' happiness in urban China? A case study of the Bohai rim area. Habitat International, 97, 102120. https://doi. org/10.1016/j.habitatint.2020.102120

De Noni, I., Orsi, L., \& Zanderighi, L. (2014). Attributes of Milan influencing city brand attractiveness. Journal of Destination Marketing \& Management, 3(4), 218-226. https://doi. org/10.1016/j.jdmm.2014.06.001

Deliktas, E., Önder, A. Ö., \& Karadag, M. (2013). The Size Distribution of Cities and Determinants of City Growth in Turkey.
European Planning Studies, 21(2), 251-263. https://doi.org/10.1080/09654313.2012.722922

Derudder, B., De Vos, A., \& Witlox, F. (2011). Global City/World City. In B. Derudder, M. Hoyler, P. J. Taylor, \& F. Witlox (Eds.), International Handbook of Globalization and World Cities (pp. 124-142). Cheltenham: Edward Elgar Publishing. https://doi. org/10.4337/9781781001011.00015

Dijkstra, L., Garcilazo, E., \& McCann, P. (2013). The Economic Performance of European Cities and City Regions: Myths and Realities. European Planning Studies, 21(3), 334-354. https://doi.org/ 10.1080/09654313.2012.716245

Duranton, G. (1999). Distance, land, and proximity: economic analysis and the evolution of cities. Environment and Planning A: Economy and Space, 31(12), 2169-2188. https://doi. org/10.1068/a312169

Duranton, G., \& Puga, D. (2014). The Growth of Cities. In P. Aghion, \& S. Durlauf (Eds.), Handbook of Economic Growth (Vol. 2, pp. 781-853). Amsterdam: Elsevier. https://doi. org/10.1016/b978-0-444-53540-5.00005-7

Duranton, G. (2016). Determinants of city growth in Colombia. Papers in Regional Science, 95(1), 101-131. https://doi.org/10.1111/pirs.12225

Ehrlich, P. R., \& Holdren, J. P. (1971). Impact of population growth. Science, 171(3977), 1212-1217. https://doi.org/10.1126/ science.171.3977.1212

European Commission. (2006). Communication from the Commission to the Council and Parliament, Cohesion Policy and cities: the urban contribution to growth and jobs in the regions (Report COM 385 final). Brussels: Commission of the European Communities. Retrieved June 15, 2021, from http://ec.europa. eu/regional_policy/archive/consultation/urban/ com_2006_0385_en.pdf

Fang, L., Lí, P., \& Song, S. (2017). China's development policies and city size distribution: An analysis based on Zipf's law. Urban Studies, 54(12), 2818-2834. https://doi. org/10.1177/0042098016653334

Fertner, C., Groth, N. B., Herslund, L., \& Carstensen, T. A. (2015). Small towns resisting urban decay through residential attractiveness. Findings from Denmark. Geografisk Tidsskrift Danish Journal of Geography, 115(2), 119-132. https://doi.org/10.1080/00167223.2015.1060863

Forrest, R., La Grange, A., \& Yip, N. M. (2004). Hong Kong as a Global City? Social Distance and Spatial Differentiation. 
Urban Studies, 41(1), 207-227. https://doi. org/10.1080/0042098032000155759

Frick, S. A., \& Rodríguez-Pose, A. (2018). Big or Small Cities? On city size and economic growth. Growth and Change, 49(1), 4-32. https://doi.org/10.1111/grow.12232

Friedmann, J. (1986). The World City Hypothesis. Development and Change, 17(1), 69-83. https://doi.org/10.1017/cbo9780511522192.019

Gabaix, X., \& loannides, Y. M. (2004). The evolution of city size distributions. In $\mathrm{J}$. V. Henderson, \& J. Thisse (Eds.), Handbook of Regional and Urban Economics (Vol. 4, pp. 2341-2378). Amsterdam: Elsevier. https://doi. org/10.1016/s1574-0080(04)80010-5

GaWC. (2021). Peter J. Taylor. Retrieved May 29, 2021, from https://www.lboro.ac.uk/ gawc/Taylor.html

Glaeser, E. L. (1998). Are Cities Dying? Journal of Economic Perspectives, 12(2), 139-160. https://doi.org/10.1257/jep.12.2.139

Glaeser, E. (2011). Cities, Productivity, and Quality of Life. Science, 333(6042), 592-594. https://doi.org/10.1126/science.1209264

Goerzen, A., Asmussen, C. G., \& Nielsen, B. B. (2013). Global cities and multinational enterprise location strategy. Journal of International Business Studies, 44(5), 427-450. https://doi.org/10.1057/jibs.2013.11

GPCI. (2013). Global Power City Index 2013. http://mori-m-foundation.or.jp/pdf/GPCI2013_ en.pdf

GPCI. (2014). Global Power City Index 2014. http://mori-m-foundation.or.jp/pdf/GPCI2014_ en.pdf

GPCI. (2015). Global Power City Index 2015. http://mori-m-foundation.or.jp/pdf/GPCI2015_ en.pdf

GPCl. (2016). Global Power City Index 2016. http://mori-m-foundation.or.jp/pdf/GPCI2016_ en.pdf

GPCI. (2017). Global Power City Index 2017. http://mori-m-foundation.or.jp/pdf/GPCI2017_ en.pdf

GPCI. (2018). Global Power City Index 2018. http://mori-m-foundation.or.jp/pdf/GPCI2018_ summary.pdf

GPCI. (2019). Global Power City Index 2019. http://mori-m-foundation.or.jp/pdf/GPCI2019_ summary.pdf
Guzmán, P. C., Roders, A. P., \& Colenbrander, B. J. F. (2017). Measuring links between cultural heritage management and sustainable urban development: An overview of global monitoring tools. Cities, 60(A), 192-201. https://doi. org/10.1016/j.cities.2016.09.005

Hansen, H. K., \& Niedomysl, T. (2009). Migration of the creative class: evidence from Sweden. Journal of Economic Geography, 9(2), 191-206. https://doi.org/10.1093/jeg/lbn046

Haque, I., \& Patel, P. P. (2018). Growth of metro cities in India: trends, patterns and determinants. Urban Research \& Practice, 11(4), 338-377. https://doi.org/10.1080/17535 069.2017.1344727

Hartt, M. (2018). The diversity of NorthAmerican shrinking cities. Urban Studies, 55(13), 29462959. https://doi.org/10.1177/0042098017730013

Heenan, D. A. (1977). Global cities of tomorrow. Harvard Business Review, 55(3), 79-92. https://doi.org/10.1002/tie.5060190313

Herrero, L. C., Sanz, J. Á., Devesa, M., Bedate, A., \& Del Barrio, M. J. (2006). The Economic Impact of Cultural Events: A Case-Study of Salamanca 2002, European Capital of Culture. European Urban and Regional Studies, 13(1), 41-57. https://doi. org/10.1177/0969776406058946

Hoechle, D. (2007). Robust Standard Errors for Panel Regressions with Cross-Sectional Dependence. The Stata Journal, 7(3), 281-312. https://doi.org/10.1177/1536867x0700700301

Hsu, W. T. (2012). Central Place Theory and City Size Distribution. The Economic Journal, 122(563), 903-932. https://doi.org/10.1111/ j.1468-0297.2012.02518.x

Huggins, R., Izushi, H., Prokop, D., \& Thompson, P. (2014). Regional Competitiveness, Economic Growth and Stages of Development. Zbornik radova Ekonomskog fakulteta u Rijeci: časopis za ekonomsku teoriju i praksu [Proceedings of Rijeka Faculty of Economics, Journal of Economics and Business], 32(2), 255-283.

Ichikawa, H., Yamato, N., \& Dustan, P. (2017). Competitiveness of Global Cities from the Perspective of the Global Power City Index. Procedia Engineering, 198, 736-742. https://doi.org/10.1016/j.proeng.2017.07.125

InterNations. (2021). Expat Insider 2021 (Survey). Retrieved June 10, 2021, from https:// cms-internationsgmbh.netdna-ssl.com/cdn/ file/cms-media/public/2021-05/InterNations_ Expat-Insider-2021_0.pdf 
Ioannides, Y., \& Skouras, S. (2013). US city size distribution: Robustly Pareto, but only in the tail. Journal of Urban Economics, 73(1), 1829. https://doi.org/10.1016/j.jue.2012.06.005

Jacobs, A. J. (2019). Global City. In A. M. Orum (Ed.), The Wiley Blackwell Encyclopedia of Urban and Regional Studies (pp. 1-10). Hoboken, NJ: John Wiley \& Sons. https://doi. org/10.1002/9781118568446.eurs0514

Johnson, B. (2008). Cities, systems of innovation and economic development. Innovation, 10(2-3), 146-155. https://doi. org/10.5172/impp.453.10.2-3.146

Kourtit, K., Nijkamp, P., \& Suzuki, S. (2013). The Rat Race between World Cities: In Search of Exceptional Places by Means of Super-Efficient Data Development Analysis. Computers, Environment and Urban Systems, 38, 67-77. https://doi.org/10.2139/ssrn.2304718

Machimura, T. (2019). World City. In A. M. Orum (Ed.), The Wiley Blackwell Encyclopedia of Urban and Regional Studies (pp. 1-8). Hoboken, NJ: John Wiley \& Sons. https://doi. org/10.1002/9781118568446.eurs0417

Marshall, J. D. (2007). Urban Land Area and Population Growth: A New Scaling Relationship for Metropolitan Expansion. Urban Studies, 44(10), 1889-1904. https://doi. org/10.1080/00420980701471943

McCann, E. J. (2004). Urban Political Economy Beyond the 'Global City'. Urban Studies, 41(12), 2315-2333. https://doi.org/10 $.1080 / 00420980412331297555$

Montalto, V., Moura, C. J. T., Langedijk, S., \& Saisana, M. (2019). Culture counts: An empirical approach to measure the cultural and creative vitality of European cities. Cities, 89, 167-185. https://doi.org/10.1016/j. cities.2019.01.014

Overman, H. G., \& loannides, Y. M. (2001). Cross-sectional Evolution of the U.S. City Size Distribution. Journal of Urban Economics, 49(3), 543-566. https://doi.org/10.1006/juec.2000.2204

Parnreiter, C. (2013). The global city tradition. In M. Acuto, \& W. Steele (Eds.), Global City Challenges (pp. 15-32). London: Palgrave Macmillan. https://doi. org/10.1057/9781137286871.0005

Partridge, M. D., \& Rickman, D. S. (2003). Do We Know Economic Development When We See It? Review of Regional Studies, 33(1), 17-39. https://doi.org/10.52324/001c.8411

Radulović, M., \& Kostić, M. (2020). Globalization and economic growth of Eurozone economies. Zbornik radova Ekonomskog fakulteta u Rijeci: časopis za ekonomsku teoriju i praksu, 38(1), 183-214. https://doi. org/10.18045/zbefri.2020.1.183

Ritchie, H., \& Roser, M. (2018, September). Urbanization. Our world in data. https:// ourworldindata.org/urbanization

Rodrigues, M., \& Franco, M. (2019). Measuring cities' performance: Proposal of a Composite Index for the intelligence dimension. Measurement, 139, 112-121. https:// doi.org/10.1016/j.measurement.2019.03.008

Romão, J., Kourtit, K., Neuts, B., \& Nijkamp, P. (2018). The smart city as a common place for tourists and residents: A structural analysis of the determinants of urban attractiveness. Cities, 78, 67-75. https://doi.org/10.1016/j. cities.2017.11.007

Sassen, S. (2004). The global city. In D. Nugent, \& J. Vincent (Eds.), A Companion to the Anthropology of Politics (pp. 168-178). New York, NY: Blackwell Publishing. https://doi. org/10.1002/9780470693681.ch11

Shearmur, R. (2012). Are cities the font of innovation? A critical review of the literature on cities and innovation. Cities, 29, S9-S18. https://doi.org/10.1016/j.cities.2012.06.008

Solá, A. G., Vilhelmson, B., \& Larsson, A. (2018). Understanding sustainable accessibility in urban planning: Themes of consensus, themes of tension. Journal of Transport Geography, 70, 1-10. https://doi.org/10.1016/j. jtrangeo.2018.05.010

Song, S., \& Zhang, K. H. (2002). Urbanisation and City Size Distribution in China. Urban Studies, 39(12), 2317-2327. https://doi. org/10.1080/0042098022000033890

Sridhar, K. S. (2010). Determinants of city growth and output in India. Review of Urban \& Regional Development Studies, 22(1), 22-38. https://doi.org/10.1111/j.1467940x.2010.00167.x

Su, H. L. (2020). On the city size distribution: A finite mixture interpretation. Journal of Urban Economics, 116, 103216. https://doi. org/10.1016/j.jue.2019.103216

Sun, B., Zhang, T., Wang, Y., Zhang, L., \& Li, W. (2021). Are mega-cities wrecking urban hierarchies? A cross-national study on the evolution of city-size distribution. Cities, 108, 102999. https://doi.org/10.1016/j. cities.2020.102999

Taylor, P. J. (1997). Hierarchical tendencies amongst world cities: a global research 
proposal. Cities, 14(6), 323-332. https://doi. org/10.1016/s0264-2751(97)00023-1

Taylor, P. J. (2001). Specification of the World City Network. Geographical Analysis, 33(2), 181-194. https://doi. org/10.1111/j.1538-4632.2001.tb00443.x

Thite, M. (2011). Smart cities: implications of urban planning for human resource development. Human Resource Development International, 14(5), 623-631. https://doi.org/1 $0.1080 / 13678868.2011 .618349$

United Nations. (2019). World Urbanization Prospects: The 2018 Revision. Retrieved August 14, 2020, from https://population.un.org/ wup/Publications/Files/WUP2018-Report.pdf

United Nations. (2020). Sustainable Cities and Communities. Retrieved August 15, 2020, from https://www.un.org/ sustainabledevelopment/cities/

Van Oort, F. G., Oud, J. H. L., \& Raspe, O. (2009). The urban knowledge economy and employment growth: A spatial structural equation modeling approach. Annals of Regional Science, 43(4), 859-877. https://doi. org/10.1007/s00168-009-0299-2

Venter, C., Mahendra, A., \& Hidalgo, D. (2019, May 28). From Mobility to Access for All: Expanding Urban Transportation Choices in the Global South. World Resources Institute. https://files.wri.org/s3fs-public/from-mobility-toaccess-for-all.pdf

Verginer, L., \& Riccaboni, M. (2021). Talent goes to global cities: The world network of scientists' mobility. Research Policy, 50(1), 104127. https://doi.org/10.1016/j. respol.2020.104127

Wang, D. D. (2019). Performance assessment of major global cities by DEA and Malmquist index analysis. Computers, Environment and Urban Systems, 77, $101365 . \quad \mathrm{https}: / /$ doi.org/10.1016/j. compenvurbsys.2019.101365

Wang, H., Cheng, Z., \& Zhu, D. (2020). Striving for global cities with governance approach in transitional China: Case study of Shanghai. Land Use Policy, 90, 104288. https:// doi.org/10.1016/j.landusepol.2019.104288

World Bank. (2020). Urban Development. Retrieved August 25, 2020, from https://www. worldbank.org/en/topic/urbandevelopment/ overview

Xu, Z., \& Zhu, N. (2009). City Size Distribution in China: Are Large Cities Dominant? Urban Studies, 46(10), 2159-2185. https://doi.org/10.1177/0042098009339432

Zenker, S. (2009). Who's your target? The creative class as a target group for place branding. Journal of Place Management and Development, 2(1), 23-32. https://doi. org/10.1108/17538330910942771

Zenker, S., Eggers, F., \& Farsky, M. (2013). Putting a price tag on cities: Insights into the competitive environment of places. Cities, 30, 133-139. https://doi.org/10.1016/j. cities.2012.02.002 